
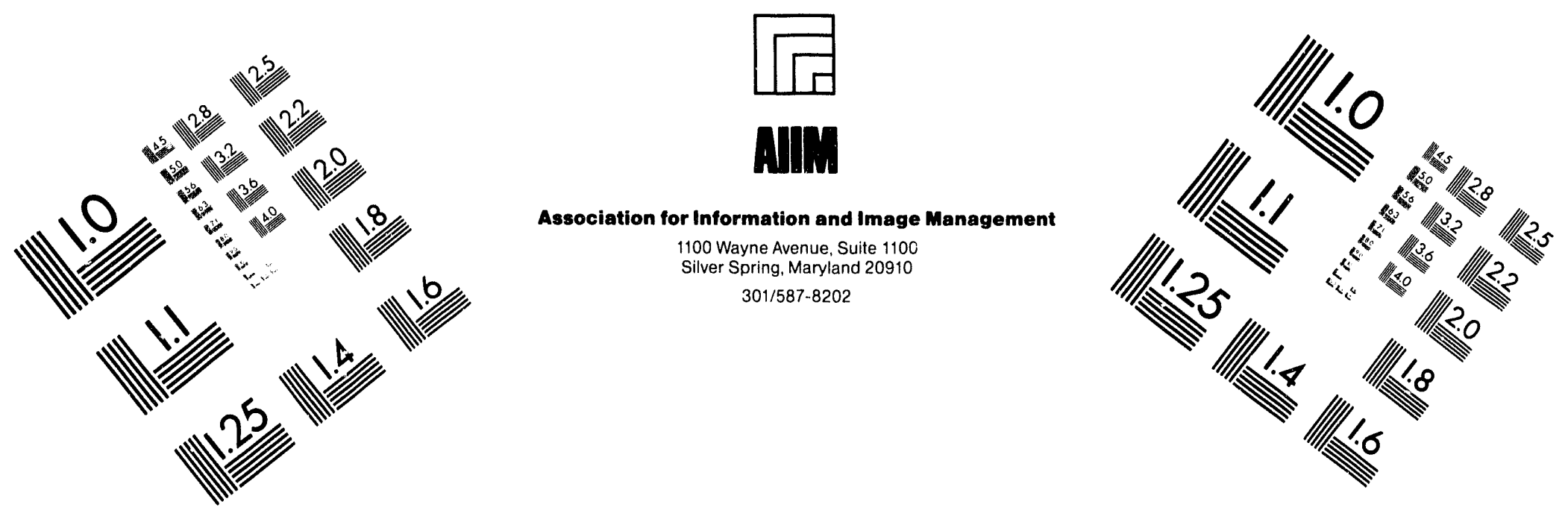

\title{
Centimeter
}

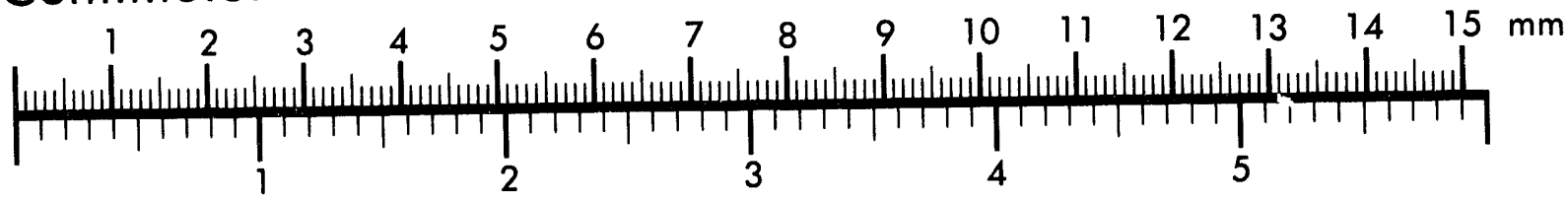
Inches

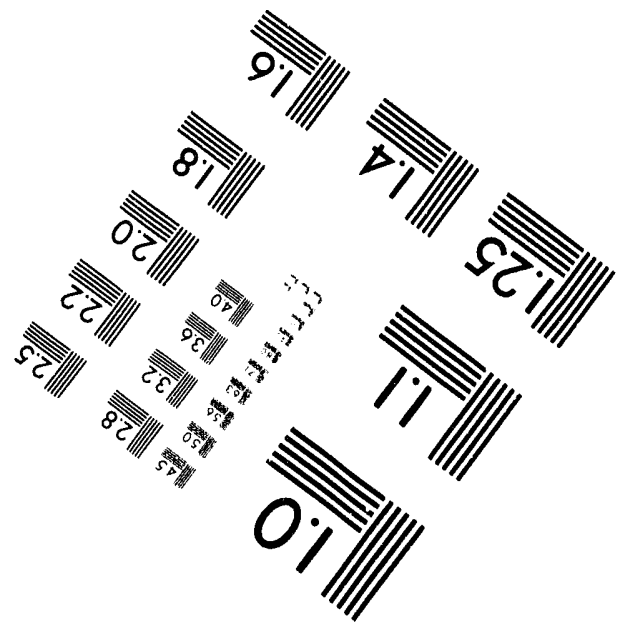

MANUFACTURED TO AIIM STANDARDS

BY APPLIED IMAGE, INC.

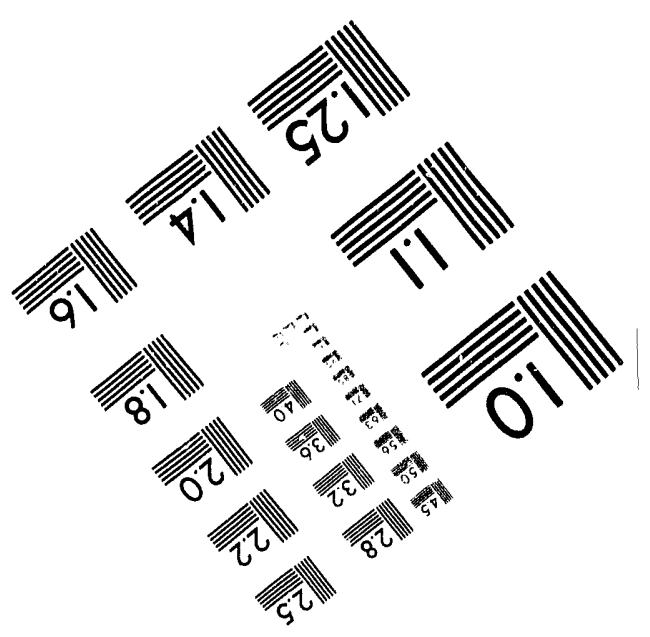



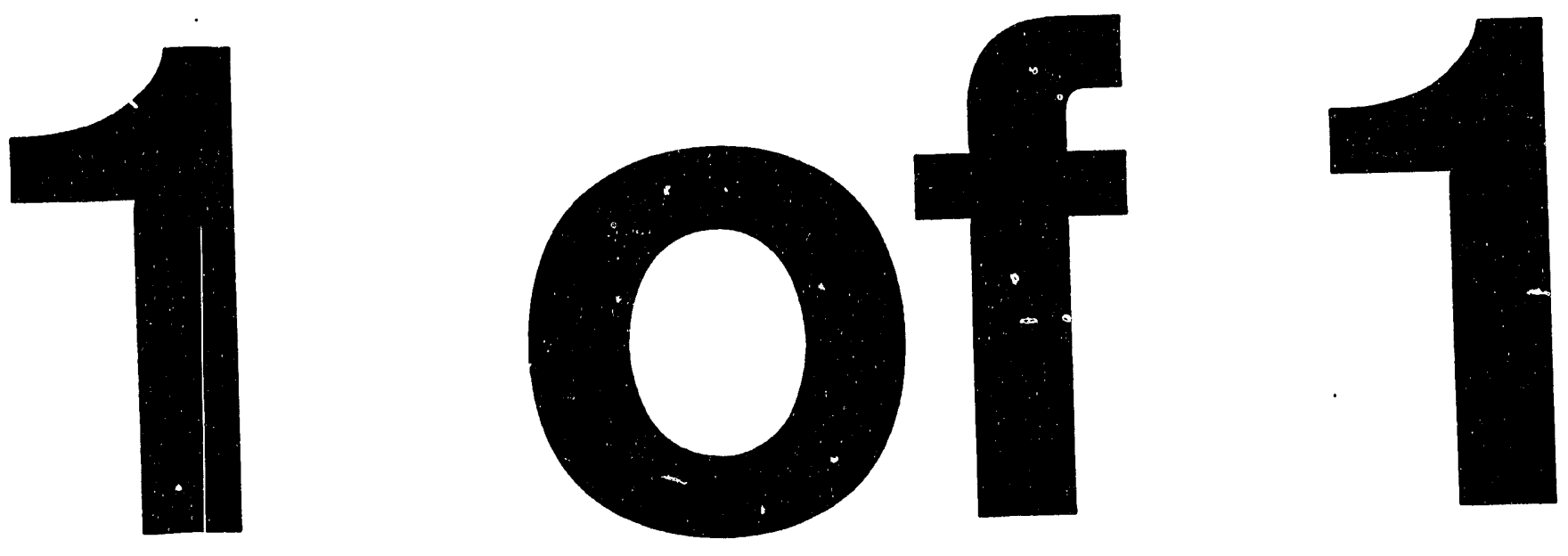
WHC-EP-0747

Revision 0

\section{Final Report of the TWRS \\ Plant Implementation Team to \\ Review Potential Reactive \\ Component in Tank 241-T-111 and Methane in Tank 241-SY-101 Gas Release Event}

D. B. Engelman

Westinghouse Hanford Company

Date Published

February 1994

Prepared for the U.S. Department of Energy

Office of Environmental Restoration and

Waste Management

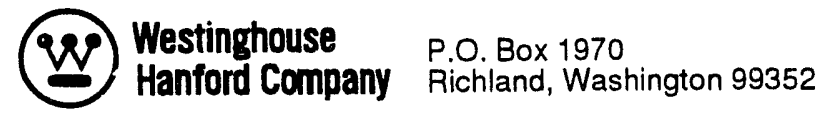

Hanford Operations and Engineering Contractor for the

U.S. Department of Energy under Contract DE-AC06-87RL10930

MASTER

Approved for Public Release

orminisution of THIS Document is unimiteo 
Document Title: Final Report of the TWRS Plant Implementation Team to Review Potential Reactive Component in Tank 241-T-111 and Methane in Tank 241-SY-101 Gas Release Event

Approved By:

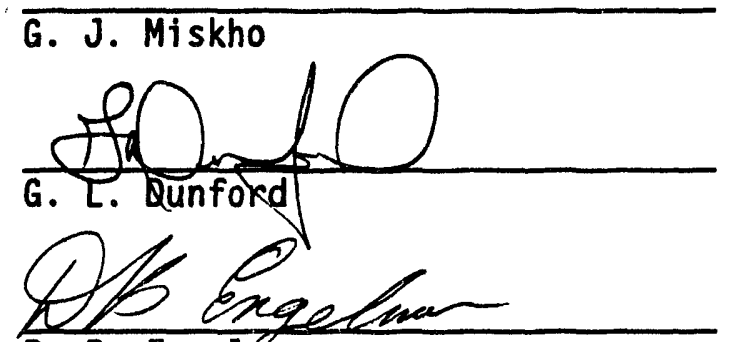

D. B. Engeliman

G. L. Borsheim
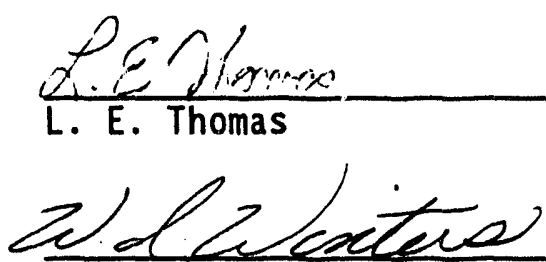

W. I. Winters
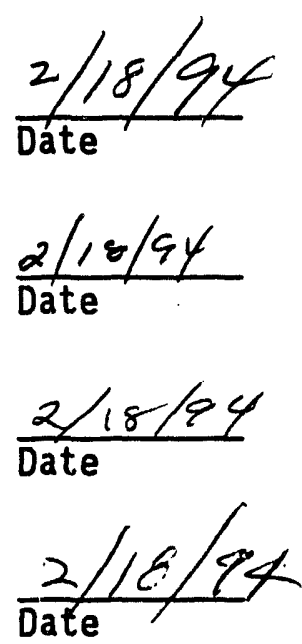

$\frac{\dot{\alpha}-j \hat{\jmath} \rightarrow 4}{\text { Date }}$

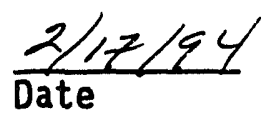




\section{CONTENTS}

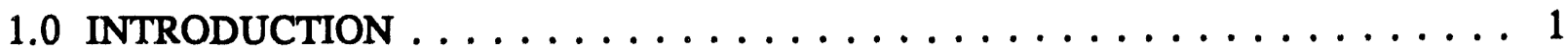

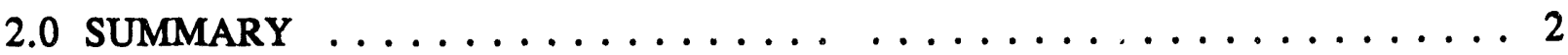

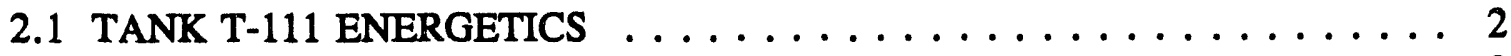

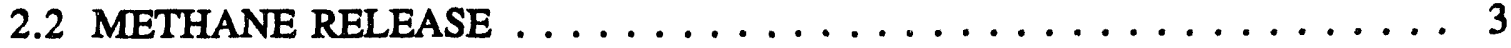

3.0 BACKGROUND $\ldots \ldots \ldots \ldots \ldots \ldots \ldots \ldots \ldots \ldots \ldots \ldots \ldots \ldots$

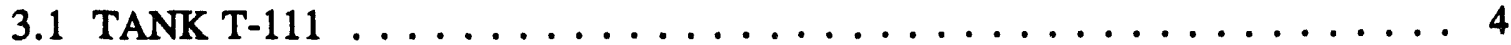

3.1 .1 Background on Tank $\mathrm{T}-111 \ldots \ldots \ldots \ldots \ldots \ldots$

3.1.2 Sampling and Extrusions ................... 5

3.1.3 Differential Scanning Calorimetry (DSC) Measurements . . . . . . . 5

3.1 .4 Data Review ........................ 6

3.1 .5 Notification ....................... 7

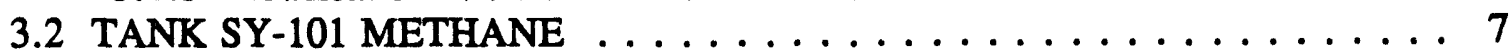

3.2.1 Background on Tank SY-101 ................ 7

3.2 .2 FTIR Operation . . . . . . . . . . . . . . . . 8

3.2 .3 LANL Analysis . . . . . . . . . . . . . . . . . . 9

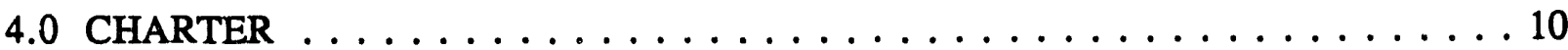

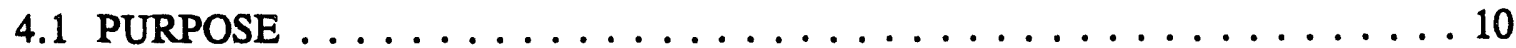

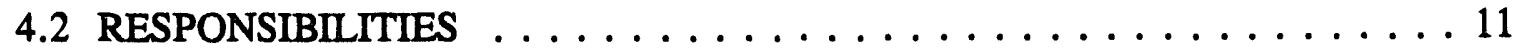

4.3 MEMBERSHIP . . . . . . . . . . . . . . . . . 11

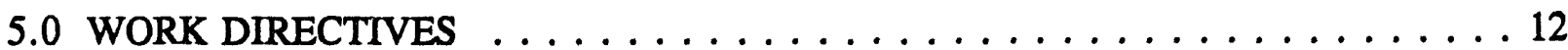

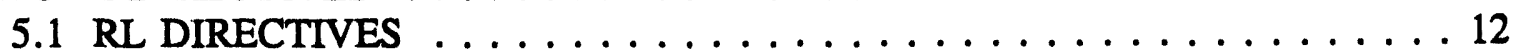

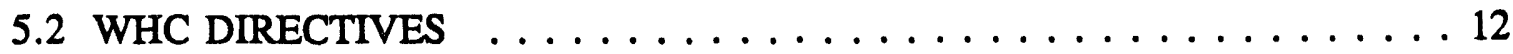

6.0 ROOT CAUSE ANALYSIS RECOMMENDATIONS AND RCA RECORD . . . . 13

6.1 TANK T-111 EXOTHERM RCA . . . . . . . . . . . . . . . 13

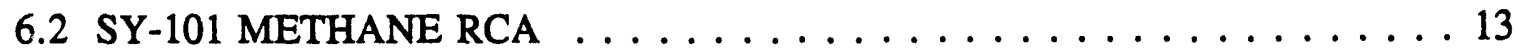

7.0 OVERALL ACTION PLAN RECOMMENDATIONS $\ldots \ldots \ldots \ldots$

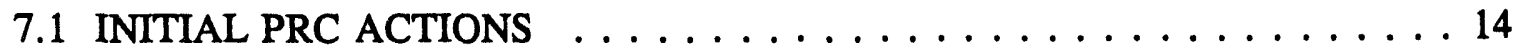

7.2 INITIAL PLANT IMPLEMENTATION TEAM ACTIONS . . . . . . . . . 15

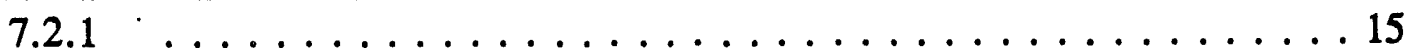

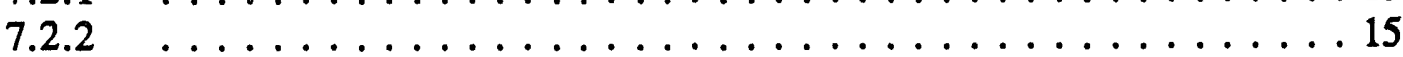

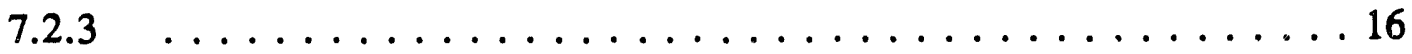

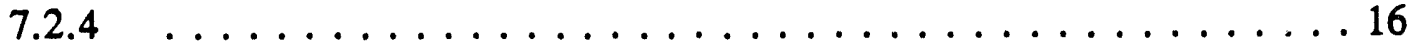


WHC-EP-0747

7.3 ISSUES AND OUTSTANDING ACTION ITEMS $\ldots \ldots \ldots \ldots \ldots \ldots$

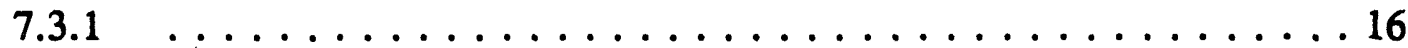

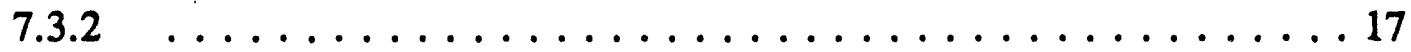

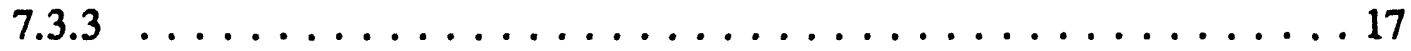

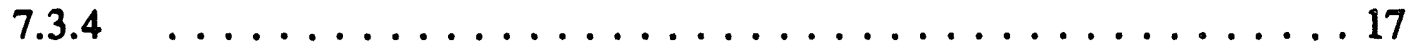

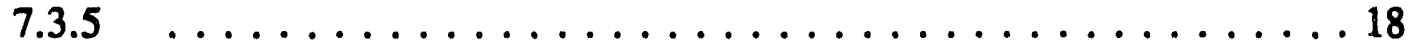

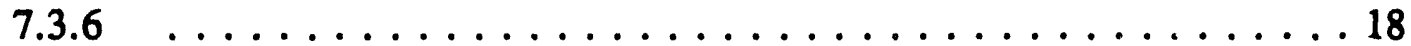

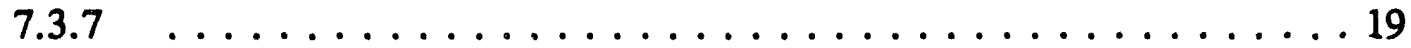

8.0 REFERENCES . . . . . . . . . . . . . . . . . . . . . . . 19 


\section{LIST OF TABLES}

$1 \quad$ DSC Core Sample Data . . . . . . . . . . . . . . . . . . . 6

2 Composition of Release Gas From Tank SY-101 Estimated From Mass

Spectrometer Data Using Argon and Oxygen as the Tie Gas . . . . . . . . . . 8 


\section{FINAL REPORT OF THE TWRS PLANT IMPLEMENTATION TEAM TO REVIEW POTENTIAL REACTIVE COMPONENT IN TANK 241-T-111 AND METHANE IN TANK 241-SY-101 GAS RELEASE EVENT}

\subsection{INTRODUCTION}

This is the final report of the results of a Tank Waste Remediation Systems (TWRS) Plant Implementation Team chartered by TWRS Operations, in response to a potential Unreviewed Safety Question (USQ) due to the discovery of a reactive component in waste tank 241-T-111 (T-111). Tank T-111, a non-Watch List single-shell tank, has no historical evidence of any potential safety problems. Core samples from tank T-111 were taken in 1991 and analyzed in 1992. The presence of uncharacterized exotherms was identified in the first three segments of two cores and reported to tank farm management in November 1993.

On December 1, 1993, the Tank Farm Plant Review Committee (PRC) (Duckett 1993) met to discuss the potential reactive component in tank $241-\mathrm{T}-111$ as a potential USQ. As a result, an off-normal event was declared and issued on December 10, 1993 (RL/WHC 1993b).

A second event, which involved data from sources external tu TWRS, also occurred in December 1993. On December 2, 1993, Westinghouse Hanford Company (WHC) was notified by Los Alamos National Laboratory (LANL) that methane gas, potentially in the amount of 1,000 ppm, was determined from Fourier Transform Infrared (FTIR) data analysis to have been present during the June 26, 1993 gas release event (GRE) of tank 241-SY-101. This was reported as an off-normal occurrence on December 3, 1993 and later upgraded to an Unusual Occurrence. On December 14, 1993, the U.S. Department of Energy, Richland Operations Office (RL) requested that WHC run a RCA on both events.

The Plant Implementation Team was chartered on December 15, 1993 (Lee 1993). The team evaluated the process that resulted in laboratory data being generated and not reviewed for over one year. This team was not involved in any other PRC responsibilities or decisions, but supplied information for PRC actions. The implementation team sponsored (1) two root cause analyses (RCAs); (2) the evaluation of other existing unreviewed data packages; (3) the re-analysis of tank T-111 samples; (4) the evaluation of other databases and data sources; and (5) the establishment of procedures and responsibilities to prevent a recurrence. When the outstanding actions contained in Section 7 are complete, the team believes that the issues raised by the PRC will be resolved and that a recurrence of this type of event will be prevented. 


\subsection{SUMMARY}

\subsection{TANK T-111 ENERGETICS}

The sequence of events is as follows.

- Tank core samples were taken on October 22, 1991 and November 5, 1991.

- The laboratory extruded core 031 on October 30, 1991 and core 033 on November 12, 1991.

- Differential scanning calorimetry (DSC) was conducted on April 6 and April 9, 1992.

- The laboratory data was formally reported on October 7, 1992.

- The validation report was completed on November 10, 1992.

- The validation report was issued to TWRS Characterization on December 11, 1992.

- TWRS characterization staff recognized a potential reactive component on November 17, 1993, and immediately informed management.

- TWRS senior management was informed of potential reactive component on November 18, 1993.

- The PRC meeting was held on December 1, 1993.

- An off-normal occurrence report was issued on December 10, 1993.

- A priority planning grid evaluation was completed on December 14, 1993.

- The TWRS Plant Implementation Team was chartered by TWRS Operations on December 15, 1993.

As a result of the actions of the Plant Implementation Team, the following actions were taken.

- A total of 12 core sample data packages were reviewed for potential safety questions. One additional tank, B-202, showed a similar exotherm. The PRC was immediately notified. 
- Preliminary notification criteria were established to identify trigger points for analytical data.

- An informal process was established at the laboratories to report analytical data out of the specified criteria to TWRS shift managers.

- The tank T-111 sample was re-analyzed and the exotherm was confirmed.

- Administrative controls were established for tanks T-111 and B-202 to treat the tank as if it were a Watch List tank until additional analyses were completed.

A RCA was completed, which focused on the causes for the delayed review of the tank T-111 data package, for safety concerns. Evaluated were two other databases, the 242-A evaporator analytical laboratory data and an emerging database, vapor sampling and analysis.

The Waste Tanks Process Control organization was assigned the ongoing responsibility to ensure that all TWRS data is reviewed for safety implications. There are several actions remaining, which must continue under the authority of existing TWRS organizations. For these open actions, interim controls are in place to ensure that there are no recurrences of a similar nature.

\subsection{METHANE RELEASE}

The sequence of events is as follows.

- In January 1993, Rev. 0 of the tank SY-101 mixer pump safety assessment was issued, which assumed a minimal concentration of methane, included in other gases.

- On June 26, 1993, a GRE occurred in tank SY-101. The FTIR was operational during this GRE.

- On July 19-21, the presence of methane was presented to the sub-TAP meeting. The significance of the finding was not realized.

- On November 30, a LANL Safety Analyst was present during discussions of methane investigations, and realized the significance of the presence of methane.

- On December 2, LANL notified WHC of the 1,000 ppm methane and its additional burn potential for the safety assessment. The maximum allowable tank level for pump operation was lowered to 406 in. to lower the allowable gas release. 
- On December 3, 1993, an off-normal occurrence report, RL/WHC 1993a, was written.

- On December 14, 1993, RL requested that WHC perform a RCA on the tank SY-101 methane release event.

- The tank SY-101 methane release event was incorporated into the Plant Implementation Team chartered on December 15, 1993.

As a result of the investigations into the methane issue, the following actions were taken.

- The maximum allowable gas release was lowered by 10 percent to allow for the presence of methane. This was achieved by lowering the maximum tank level for pump operation to 406 in.

- A RCA was completed for the tank SY-101 methane release event.

The corrective actions from the RCA included:

- LANL instituted monthly status meetings for the Gas Analysis and Safety Assessment Groups.

- TWRS to appoint a point of contact who is responsible for archiving the data, gathering the tank data from all groups developing or obtaining the data, assuring the data is valid, disseminating the data to the affected or appropriate groups, conducting briefings or discussion sessions, and assuring that new data, or data changes, are compared to that used to determine the envelope given by the safety document.

The team believe that when the actions listed in Section 7 are complete, no further actions will be necessary to correct this root cause and prevent a similar recurrence.

\subsection{BACKGROUND}

\subsection{TANK T-111}

\subsubsection{Background on Tank T-111}

Tank T-111 is a non-Watch List single-shell tank with no prior indication of any potential safety issue. All waste receipts were second-decontamination cycle bismuth 
phosphate waste (2C), 224 waste (the final decontamination and purification step in the bismuth phosphate process), and T-Plant decontamination waste solutions. Flowsheet records indicate that small amounts of oxalate were present in 224 waste.

- In service: $10 / 45$

- Out of service: $4 / 74$.

The tank volume is $530,000 \mathrm{gal}$ with $458,000 \mathrm{gal}$ of waste (approximately 9 core sample segments in depth). The highest temperature recorded in 1992 was $71.8{ }^{\circ} \mathrm{F}$.

\subsubsection{Sampling and Extrusions}

Chain-of-custody records for the first three segments of core 031 show the core was taken from riser \#6 on October 22, 1991 and received by the 222-S Laboratory on October 23, 1991. Core 033 was taken from riser \#3 on November 5, 1991 and received by the 222-S Laboratory on November 6, 1991.

The laboratory core extrusion description sheet for core 031, segment 1 (extruded 10/30/91) shows that "the extruder was mostly empty with about 50 milliliters (mls) of black brown low viscous solids." The extruded liquid was described as "looking like NPH, dirty, not very clear and definitely contains some solids." The description sheet for segment 2 , which was extruded on October 30,1991, stated that "the extruder was completely full of solids with very little extruder liquid, less than $3 \mathrm{ml}$." No extruder liquid was collected; however, the liner liquid was described as having "two phases with equal parts of NPH and water." Segment 3 (extruded October 31, 1991) was completely full of solids and no extruder or liner liquids were noted. Core 033, segments 1,2, and 3 (extruded November 13, 1991) were all completely filled with solids with no extruder or liner liquids noted.

\subsubsection{Differential Scanning Calorimetry (DSC) Measurements}

Core 031 , segments 1, 2, and 3 were all examined by DSC on March $31,1992$. Core 033, segments 2 and 3 were tested on April 6, 1992 and segment 1 was tested on April 9, 1992. All measurements were made directly on unhomogenized samples. The data from the DSC and percent water run sheets are shown in Table 1. Exotherm values are based on wet weight of sample. 


\subsubsection{Data Review}

The Characterization analyst began a review as preparation for a Tank Characterization Report (TCR) on November 11, 1993. This delay from October 1992 was because of ferrocyanide and tank SY-101 itemls that were a higher priority and had precedence in resource allocation.

Exotherms were detected in segments 1,2, 3 and 4 on core 31 ; and segments 1, 2, and 3 on core 33. They were reported to be similar in size and temperature range. They are summarized in Section 3.2.

Table 1. DSC Core Sample Data.

\begin{tabular}{|l|l|l|l|l|}
\hline Core & Segment & Endotherm & Exotherm & Water \\
\hline 031 & 1 & $1406 \mathrm{JJ} / \mathrm{g}$ & $259 \mathrm{~J} / \mathrm{g}$ & $80.8 \%$ \\
\hline & 1 (Dup) & $1089 \mathrm{~J} / \mathrm{g}$ & $278 \mathrm{~J} / \mathrm{g}$ & $79.8 \%$ \\
\hline 031 & 2 & $1108 \mathrm{~J} / \mathrm{g}$ & $256 \mathrm{~J} / \mathrm{g}$ & $82.4 \%$ \\
\hline 031 & 3 & $1210 \mathrm{~J} / \mathrm{g}$ & $448 \mathrm{~J} / \mathrm{g}$ & $82.2 \%$ \\
\hline 033 & 1 & $1604 \mathrm{~J} / \mathrm{g}$ & $293 \mathrm{~J} / \mathrm{g}$ & $80.4 \%$ \\
\hline & 1 (Dup) & $958 \mathrm{~J} / \mathrm{g}$ & $218 \mathrm{~J} / \mathrm{g}$ & $79.8 \%$ \\
\hline 033 & 2 & $1346 \mathrm{~J} / \mathrm{g}$ & $455 \mathrm{~J} / \mathrm{g}$ & $80.6 \%$ \\
\hline & 2 (Dup.) & $1496 \mathrm{~J} / \mathrm{g}$ & $645 \mathrm{~J} / \mathrm{g}$ & $79.8 \%$ \\
\hline 033 & 3 & Not calc. & $49 \mathrm{~J} / \mathrm{g}$ & $81.9 \%$ \\
\hline \multicolumn{5}{|l}{$3 / \mathrm{g}=$ Joules/gram (J/g $=0.239 \mathrm{cal} / \mathrm{g})$} \\
\end{tabular}

NOTE: This data was formally reported in WHC $1992 \mathrm{~b}$.

Subsequent to the original analysis of tank $241-\mathrm{T}-111$, a screening criteria of $125 \mathrm{cal} / \mathrm{g}$ on a dry weight basis was established for tank samples. The analyst recognized that the values of Table 1 , when converted to a dry weight basis, exceeded this screening criteria.

There is the potential for an energetic layer of material towards the top of tank 241-T-111. The fuel source at this time is unknown; present analytical results do not indicate ferrocyanide or organics in sufficient quantity to produce results as energetic as this. Laboratory investigations are continuing. However, the amount of sample material available for laboratory analysis is very limited; further analysis will be accomplished in accordance with an integrated, prioritized analytical plan. 


\subsubsection{Notification}

On November 17, 1993, the Characterization Program Manager was notified by an analyst of the unusual exotherms. On November 18, the Characterization Program Manager notified Operations and management of the issue. RL and the U.S. Department of Energy, Headquarters (DOE-Fi) were notified at the same time. The RL Tank Operations Office Manager was notified on November 30, 1993.

\subsection{TANK SY-101 METHANE}

Tank 241-SY-101 has exhibited cyclic gas release behavior since the early 1990s. A project team was established in early 1992 for the purpose of mitigating the gas release behavior. This project team is led by WHC and has additional engineering, mitigation operators, QA and safety oversight personnel. LANL personnel are included in the project team for gas analysis support and preparation of safety analysis documents.

\subsubsection{Background on Tank SY-101}

Tank SY-101 is a double-shell, high-level waste tank located in the 200 West Area of the Hanford Site. Construction of the tank was completed in 1976 and the first waste was placed into the tank in 1977. A volume corresponding to a height of one hundred inches of double-shell slurry from the 242-S Evapu-sist was pumped into tank SY-101 (Babad et al. 1991).

From 1977 to 1980 , the tank received complex concentrate waste. Complex concentrate waste is a waste from the cesium/strontium recovery process in B Plant. A total of 203 in. of this waste was placed on top of the double-shell slurry. In the fall of 1980, approximately 84 in. of double-shell slurry was added into tank SY-101. This was the last waste material placed into the tank. Purge water totaling 8,000 gal was added to the tank between September 1984 and May 1988.

Episodic gas releases in this tank are caused by a phenomenon termed slurry growth. This phenomenon involves the generation and entrapment of gas produced from the degradation of organic compounds contained in the tank waste. The gas formed from the reactions is composed primarily of hydrogen, nitrous oxide, and nitrogen (Burke et al. 1991a; Burke et al. 1991b).

Slurry growth, as indicated by episodic increases and decreases in waste depth, was detected as early as 1980 . The report (Delegard 1980) identified the growth as a result of gas generation within the waste. The report also identifies gases produced in simulated waste tank experiments, listing methane at 2.3 mole percent. The Tank Waste Science Panel, as shown by the Panel's 1990 and 1991 meeting minutes (PNL-7598, PNL-7599, PNL-8048, PNL-8047, PNL-8845), used this report as reference material in its discussions. 
Beginning in 1990, WHC undertook an ongoing vapor sampling effort for tank SY-101. Significant efforts to measure the composition of the gas released during an event began with the April 1990 GRE. During this release the first use of standard gas chromatograph/mass spectrometer techniques to estimate the composition of the release was accomplished. These measurements were made from grab samples obtained from a sample line installed on the exhaust header of tank SY-101. In an effort to reduce the component variances, WHC installed an online mass spectrometer and additional in-tank sampling ports in May of 1991 so that gas composition at various heights in the dome could be measured.

Methane is listed occasionally in GRE evaluations in varying amounts but no higher than 0.04 mole percent mixed in the dome space and in the past has never been in sufficient amount to be considered a concern. The estimates for release gas composition using these data was given in Reynolds (1992). These were the basic data used in preparation of Appendix C of LA-UR-92-3196 (Edwards 1993). The appendix also lists 0.5 percent "other" gases of which methane, along with carbon monoxide and carbon dioxide, is mentioned. Table 2 lists the gas composition used in preparation of Appendix $\mathbf{C}$ to the safety assessment.

Table 2. Composition of Release Gas From Tank SY-101

Estimated From Mass Spectrometer Data Using Argon and Oxygen as the Tie Gas.

\begin{tabular}{|l|c|c|}
\hline \multicolumn{1}{|c|}{ Species } & Argon tie gas & Oxygen tie gas \\
\hline Hydrogen & $40+/-.4 \%$ & $33.2+/-4.8 \%$ \\
\hline Nitrous oxide & $32.9+/-1.3 \%$ & $28.6+/-5.2 \%$ \\
\hline Nitrogen & $28+/-2.1 \%$ & $37.7+/-8.7 \%$ \\
\hline Other & $0.5 \%$ & $0.5 \%$ \\
\hline
\end{tabular}

\subsubsection{FTIR Operation}

In October of 1992, the FTIR spectrometer system was installed by WHC in an effort to enhance worksr safety by eliminating the need for personnel on the tank during GREs. The FTIR replaced the organic vapor monitor (OVM), which had been used to monitor ammonia and organic vapors. The spectrometer sends an infrared beam through a gas mixture and identifies the mixture's composition based on the resulting spectrum. Unlike the OVM, which only identifies if an organic is present, this instrument can identify and quantify most individual species in a gas mixture (WHC, 1993b).

The FTIR became operational on November 6, 1992, and has run relatively well for the last eight months. The system at tank SY-101 consists of several components. Specifically, they are the FTIR optical bench, power supply, chiller, SPC3200 control computer, and "Kenetics" host computer. In operation, these samples are subjected to an 
infrared light source and scanned for a total of 64 scans. The results for these 64 scans are averaged and the spectral data is calculated and stored on the SPC3200 computer. The raw spectral data is then transmitted to the Kenetics computer in the Data Acquisition Control System (DACS) over a dedicated ethernet. In the Kenetics, the spectral data is used to calculated the concentration of ammonia and nitrous oxide then the results of the analysis are appended to an ASCII file which is stored on the Kenetics. The raw spectral data is also stored on the Kenetics computer. All operations are done automatically. After the completion of one analysis, another one starts until the operation is terminated by the user or the system is interrupted.

The summary ASCII report and raw spectral data for each analysis is stored on the Kenetics computer in DACS. The ASCII summary file consists of a field for each analysis detailing the date, time, area for each gas, concentration for each gas, and corresponding raw spectral data file. A copy of the summary ASCII file for the previous day is transmitted daily to WHC Waste Tanks Process Control organization and posted to the WHC324IRAW server.

Raw spectral data and the summary ASCII report are also archived to 90MB Bernoulli drives. After this data is transmitted to LANL for offline verification and identification of requested gas streams the Bernoulli data are sent to the Waste Tanks Process Control orgarization for archiving.

\subsubsection{LANL Analysis}

The FTIR, at the time of the June 26, 1993, GRE, had preset calibrations to monitor for low (PPM range) concentrations of ammonia and nitrous oxide. This was also the first time data had been captured on the FTIR during a gas release event. When the GRE occulred, the quantities of gases released saturated the spectrum making the readouts in the DACS trailer/unusable. The data was then transferred to LANL, per charter, for more complete analysis. During the performance of the data analysis for ammonia and nitrous oxide (between June 27 and July 3, 1993), a LANL analyst recognized the unique methane signature in the spectrum and determined the amount to be $1,000 \mathrm{ppm}$ plus or minus 50 percent, with the need for further analysis to be more specific on the amount.

On July 2, 1993, the LANL scientist responsible for FTIR data sent a telefax to LANL representatives at the Hanford Site, indicating the $1,000 \mathrm{ppm},+1-50$ percent methane. This information was later presented to the July sub-TAP (Tank Advisory Panel) meeting held in Richland, Washington. The particular sub-TAP meeting at which the data was presented was attended by representatives from LANL, WHC, RL, DOE-HQ, Pacific Northwest Laboratory (PNL), and other organizations.

LANL was performing ammonia and nitrous oxide concentration analysis and burn analysis, in a attempt to resolve the potential ammonia USQ during the July to November time frame. Also, in recognizing the need to validate the finding of $1,000 \mathrm{ppm}$ methane 
concentration, LANL proceeded to procure more instrumentation and architect future work to further refine the measurement of methane concentration. LANL further provided WHC, around September 1993, with task descriptions for performance of these activities during 1994. WHC compared those tasks with the DOE requirements and judged them outside the scope of DOE requirements in SY-101 tank mitigation plans and, hence, turned those tasks down.

No further action was taken regarding methane until November 30, 1993, when the LANL Safety Analysis group was informed of the importanc:e of refining the methane estimate.

\subsection{CHARTER}

\subsection{PURPOSE}

The TWRS Plant Implementation Team was established to identify and implement policies, practices, and staff training necessary to upgrade the laboratory/TWRS interface. The team was charged with defining and implementing a highly sustainable process to ensure early discovery of data anomalies in waste tank sample results and rapid and timely evaluation and reporting of these data anomalies to Plant Operations. The team's scope included the following tasks.

- Develop criteria for early screening for anomalous data and potential safety personnel issues.

- Develop process and responsibilities for technical review and subsequent early warning at the analytical data release stage with continuing input through TCR.

- Develop red flag notification and issue resolution process.

- Define operations/engineering responsibilities for action and control including USQ screening and PRC review of potential USQs.

- Define requirements for operations notification and corrective actions.

- Develop schedule and action item assignments to develop and implement policy/procedures and training.

- Extend this process to other critical databases (i.e., safety, process control, disposal, vapor program, effluents and WAPs, solid waste characterization data base, and surveillance). 


\subsection{RESPONSIBIITIES}

In addition the aforementioned duties, the team was directed to assume the following responsibilities.

- Define the basic philosophy that should exist when operational elements depend on offsite or inter-organizational groups for analytic work to support real-time compliance needs.

- Interface with the President's Conduct of Operations Council to ensure that lessons learned from the review are communicated to all operational units of WHC. In addition, these lessons should be incorporated in the W-GOBU Conduct of Operations manual, as appropriate.

- Conduct RCA to investigate the circumstances relating to the potential discovery of a reactive component in tank 241-T-111 based on 1991/1992 samples and analysis, the potential for elevated levels of methane in the vapor space of tank 241-SY-101, as noted by LANL personnel (see RL/WHC 1993a), and the inadequate sampling program for plutonium content in the $\mathrm{K}$-Basin sand filter back wash pit that led to a USQ. These events share a common theme in that the operating and analytic organization interfaces were not adequate to ensure accurate, timely and meaningful communication.

\subsection{MEMBERSHIP}

The initial team consisted of the following memibers.

G. J. Miskho, Team Leader

J. R. Kasper, Operations

G. L. Dunford, Operations

D. B. Engelman, Plant Engineering

G. L. Borsheim, Process Engineering

L. E. Thomas ESQ, Certified AI.

W. I. Winters, Laboratory 


\subsection{WORK DIRECTIVES}

\subsection{RL DIRECTIVES}

In a letter from RL (Anttonen 1993), TWRS was requested to perform a RCA on the delayed review of Tank Characterization Data for tanks T-111 and SY-101. Two separate RCA teams were formed. One focused on the delay in the review of core sample analytical data from T-111, and the other on the discovery of methane in SY-101. This plan was reported back to DOE in letter number 9309029B-R1 (Defigh-Price 1993).

\subsection{WHC DIRECTIVES}

Initial direction from the PRC and the Plant Implementation Team were as follows.

- "Establish safety flags and appropriate technical basis and have the remaining raw sample data screened with these flags to verify that there are no other safety concerns. This screening should be accomplished quickly and should not interfere with meeting the 20 TCRs that are due to the Washington Department of Ecology by September 1994. A formal report should be issued to the team.

- The detailed TCD characterization sample process should be completed as soon as possible, then controlled by procedure which should include safety flags for early screening and discovery of data anomalies and follow-on evaluation and reporting to Tank Farm Plant Operations. Both WHC and PNL should be included in this process. A WHC TWRS-responsible person should be put in full charge of this TCD formal process and be held accountable for configuration and change control.

- The tank 241-T-111 event occurrence report (RL-WHC-Tank Farm-1993-0110) of December 1, 1993, should be evaluated to determine if we actually had a safety problem, including appropriate overview by Environmental Safety and Quality representative and safety analysis expertise. A report should be issued to the team." 


\subsection{ROOT CAUSE ANALYSIS RECOMMENDATIONS AND RCA RECORD}

\subsection{TANK T-111 EXOTHERM RCA}

A RCA was conducted by the RCA Team on January 11, 1994. Table 4-1, Root Cause Analysis (Homi 1994) Section 4.0 (WHC 1993a) was used as the information guide for the analysis. The analysis technique used was the root cause determination matrix and direct cause (subject) code (Table 4-2). The priority planning grid value was 5.0, as determined by the TWRS Corrective Action Evaluation Group. The priority planning grid results were entered in the Quality, Environmental, Safety Tracking (QUEST) system as ORT-93-0110-TANKFARM, Potential Reactive Component Discovered Single Shell Tank.

The direct cause was determined to be defective or inadequate procedure (2A) because specific flagging and reporting instructions were not included in the applicable work directives. The root cause was determined to be inadequate administrative control (6A) because no criteria had been established for early screening and notification of anomalous data. A RCA record form was completed. For more details refer to Nau 1994.

The following is a list of the recommendations made by the RCA tean.

- Develop criteria for early screening for anomalous cata and potential safety personnel issues.

- Develop process and responsibilities for technical review and subsequent early warning at the analytical data release stage with continuing input through TCR.

- Develop red flag notification and issue resolution process.

\subsection{SY-101 METHANE RCA}

The RCA team for the tank SY-101 methane event used a tree analysis to ensure that all aspects of the investigation were considered, and then used a change analysis to determine the root cause.

LANL has been contracted by WHC to perform work leading to a safety assessment to allow mixer pump operation in tank SY-101 as well as to calibrate the FTIR for routine, real-time analysis of ammonia and nitrous oxide. In addition, WHC retains its own gas analysis group and a gas monitoring group. PNL also performs gas analysis. $\mathrm{RL}$ and DOE-HQ have oversight responsibilities for these activities. Routine problems and information are relayed via phone conversations, Test Review Group meetings, TAP meetings, and onsite visits. There are no procedures in place for a direct, early review of information which may have a safety context, especially where more than one organization or company is involved. The direct cause was determined to be Management Methods--Lack of 
Formal Reporting Method Results in Communication Gap. If a specific notification procedure been in place, the potential significance of the amount of methane in relation to its added burn energy for the safety assessment would have likely been recognized much faster. Instead, the 1,000 ppm methane data was over-shadowed by the possible ammonia USQ, the pump becoming plugged, and all the other information which results from a GRE. The lack of a formal reporting method, coupled with the lack of attention to the significance of the data being presented, led to the determination of a root cause defined as: Management problem/administrative controls less than adequate.

\subsection{OVERALL ACTION PLAN RECOMMENDATIONS}

\subsection{INITIAL PRC ACTIONS}

The meeting of the PRC in December 1993 established these actions for the Plant Implementation Team.

1. Examine the present data package for additional clues with regards to the presence of these exotherms (DSC baseline, TOC values, total $\mathrm{CN}$ values, moisture).

2. Investigate the historical information further on tank 241-T-111 (plant effluents, tank transfers) to determine the potential sources of fuel.

3. Determine if sample material from the top three segments of cores 31 and 33 are available to do further testing on. If further sample is available, some sigested assays (in order of priority) are as follows.

- Adiabatic calorimetry on core 31 and 33 material; segments 1-3.

- After drying the material under vacuum at $60^{\circ} \mathrm{C}$, re-run the DSC on core 31 and 33 material; segments 1-3, under an inert atmosphere.

- Perform a total CN measurement with the newly developed method.

- Re-check the TOC and total carbon numbers, especially with potential NPH contamination.

These actions were completed, as described in Turner (1994). 


\subsection{INITIAL PLANT IMPLEMENTATION TEAM ACTIONS}

When the Plant Implementation Team met, it refined and added to these actions, as described below.

\subsection{1}

"Establish safety flags and appropriate technical basis and have the remaining raw sample data screened with these flags to verify that we have no other safety concerns. This screening should be accomplished quickly and without interference to meeting the 20 Tank Characterization Reports (TCR) due to Washington Department Of Ecology by September 1994. A formal report should be issued to the team. Action: D. B. Engelman."

TWRS uses a Data Quality Objective (DQO) process to develop requirements for sampling and analysis. To establish red flags for the identification of safety issues, a DQO called the safety screening DQO is used. This will establish the technical basis for the flags.

Because this DQO is not complete, an interim list of safety flags was used as the basis evaluation of the twelve outstanding data packages. This list was developed by the TWRS Safety Program (Babad 1993). A formal report of the results was issued (Kristofzski 1994). This report must be reviewed and modified, if necessary, after the formal safety flags are established.

\subsection{2}

"The detailed TCD characterization sample process should be completed as soon as possible, then controlled by procedure which should include safety flags for early screening and discovery of data anomalies and follow-on evaluation and reporting to Tank Farm Plant Operations. Both WHC and PNL should be included in this process. A WHC TWR:responsible person should be put in full charge of this TCD formal process and be held accountable for configuration and change control. Action: D. B. Engelman."

The characterization process is controlled by the following documents: Data Quality Objectives, TWAP, and TCPs. The DQOs establish the technical basis for the limits. The TWAP describes the process for integrating the DQO requirements and how they are to be implemented. The TCP contains the tank specific instruction to the laboratories for performing the analyses and reporting results for that activity, including action limits and early notification to operations. 


\subsection{3}

"The tank 241-T-111 event occurrence report (RL-WHC-Tank Farm-1993-0110) of December 1, 1993, should be evaluated to determine if we actually had a safety problem, including appropriate overview by Environmental Safety and Quality representative and safety analysis expertise. A report should be issued to the team. Action: D. A. Turner. This action has been completed, as described in Turner (1994)."

\subsection{4}

The evaporator interface to the laboratory was evaluated. The existing MOU between the evaporator operations and the laboratory organization should be improved to include . screening for safety data and immediate notification of the 242-A Evaporator shift manager's office in case anomalous data is discovered. This must include training, for both laboratory personnel and Evaporator operations personnel. This action has been completed, as described in Ross (1994).

\subsection{ISSUES AND OUTSTANDING ACTION ITEMS}

\subsection{1}

An interim procedure has been established at the laboratories, based on preliminary flags developed by the TWRS Safety Program. The list of analytes and limits which constitute these flags was not formalized into a requirement to the laboratory until directed by this team, and does not have a documented technical basis.

This safety list will be used as an interim list. All outstanding data packages have been reviewed against it. This list will continue to be used, until a technically defensible list is developed and formally issued.

\section{Actions}

7.3.1.1. Complete the development of the Data Quality Objective for safety screening. This will result in a technically defensible basis for safety limits. (J. R. Mobley 3/1/94)

7.3.1.2. Evaluate the initial safety list for changes, and reevaluate the existing data packages as required. (D. R. Bratzel 4/1/94)

7.3.1.3. Formally transinit procedural direction to the analytical laboratories, requiring that these limits be built into the laboratory process. This direction should also include notification requirements to TWRS management. (D. R. Bratzel 3/1/94) 
7.3.1.4. Develop procedures to be incorporated into WHC (1992a) within TWRS which detail responses to notification, when received from the laboratories. Incorporate these procedures into the shift managers, shift engineers, and systems engineers training. (D. B. Engelman 5/15/94)

\subsection{2}

Twelve existing data packages have been reviewed. Tank B-202 was discovered to also have an unknown energetics source. These data packages were reviewed against a preliminary list of safety analytes.

\section{Actions}

7.3.2.1. After issuing the formal red flag limits, review and revise report as required. (C. S. Haller 4/1/94)

\subsection{3}

A preliminary process has been developed, which details the flow of data from the laboratories to the Characterization Program. This process must be formalized and configuration controlled through the formal document Tank Waste Analysis Plan (TWAP), which is a formal controlled document (also a TPA deliverable, approved by the state). Procedures at the laboratory and TWRS must reflect this process. In particular, a TWRS procedure must exist, with a responsible organization and manager, which requires the review of all new data for safety implications as soon as the data are available.

\section{Actions}

7.3.3.1. Complete and issue the TWAP, detailing the Characterization Process. Incorporate safety review criteria and notification system in the final TWAP and assign responsibility for the control of the process. (D. R. Bratzel 3/15/94)

7.3.3.2. Develop a comprehensive TWRS procedure for early screening of all existing and emerging data for safety implications, and include immediate notification of Tank Farm Operations shift manager upon discovery of anomalies, to be included in WHC (1992a). (D. B. Engelman 5/15/94)

\subsection{4}

The PRC question asked if there is an imminent safety hazard associated with the reactive component in tank $241-\mathrm{T}-111$ core samples? If there is, is a propagating exothermic chemical reaction a credible event under existing waste storage conditions? 
The conclusion is that the waste is conditionally safe provided the moisture content remains high and the waste temperature remains low. The exothermic activity of the reactive component is too low, under existing waste storage conditions, to support a propagating exothermic chemical reaction.

However, the total organic content (TOC) of the waste falls short by a factor of about four in accounting for the observed exothermic activity $(123 \mathrm{cal} / \mathrm{g}$ vs. $447 \mathrm{cal} / \mathrm{g}, \mathrm{D}$. A. Tumer (1994) (7A700-94-002). Work is ongoing to determine the source of the exotherms.

\section{Actions}

7.3.4.1. Prepare, approve, and issue an integrated, prioritized analytical plan to investigate the exotherm source. (D. A. Turner 3/1/94)

\subsection{5}

As a result of the two RCAs and team review of tank T-111, 242-A, and the vapor database, it is concluded that a comprehensive procedure is necessary to ensure prompt review of all data against formal safety flags and to insure immediate notification to shift manager when anomalies are discovered.

\section{Actions}

7.3.5.1. Fully implement the TWRS procedure (Action number 7.3.3.2) for review of all existing and emerging tank data, from any source, for safety implications. This responsibility has been assigned to the manager of Waste Tanks Process Control. Implementation should include (1) early screening of safety criteria against other databases including vapor database, mitigation, TCD; and (2) routine evaluation of other existing or emerging databases.

(N. W. Kirch $7 / 1 / 94$ )

\subsection{6}

The lessons learned from these events must be incorporated into the lessons learned and/or Conduct of Operations programs.

\section{Actions}

7.3.6.1. Incorporate results into lessons learned program. (D. L. Burt 5/1/94)

7.3.6.2. Brief President's Conduct of Operations Council to assure the lessons learned are communicated to all operational units of WHC, and incorporated into W-GOBU Conduct of Operations Manual as appropriate (G. J. Miskho 3/16/94). 


\subsection{7}

Submit all open action items into QUEST and track 45 days after issuance of report. (G. J. Miskho)

\subsection{REFERENCES}

Anttonen, J. H., 1993, Request for an Immediate Root Cause Evaluation of the Delayed Analysis of Tank Characterization Data For Waste Tanks T-111 and SY-101, (Letter 93-CST-063 to T. M. Anderson, December 15, 1993).

Babad, H., 1993, A Strategy for an Early Warning Notification System, (Letter to J. G. Propson, April 26, 1993), Westinghouse Hanford Company, Richland, Washington.

Babad, H., G. D. Johnson, J. A. Lechelt, D. A. Reynolds, L. R. Pederson, D. M. Strachan, D. Meisel, C. Johnah, and E. C. Ashby, 1991, Evaluation of the Generation and Release of Flammable Gases in Tank 241-SY-101, WHC-EP-0517, Westinghouse Hanford Company, Richland, Washington.

Burke, T. M., K. G. Carothers, S. M. Joyce, and A. L. Pajunen, 1991a, WHC-SD-WMPE-039, Evaluation of April 19, 1990, Tank 241-SY-101 Gas Release Event, January.

Burke, T. M., K. G. Carothers, and D. A. Reynolds, 1991b, Evaluation of August 5, 1990 , Tanks 241-SY-101 Gas Release Event, WHC-SD-WM-PE-040, Westinghouse Hanford Company, Richland, Washington, June.

Defigh-Price, C., 1993, Request for an Immediate Root Cause Evaluation of the Delayed Analysis of Tank Characterization Data for Waste Tanks 241-T-111 and 241-SY-101; Westinghouse Hanford Company Tank Waste Remediation System Reply for Charter, Plan and Schedule, (Letter \#9309029B R1 to J. H. Anttonen, December 21, 1993), Westinghouse Hanford Company, Richland, Washington.

Delegard, C., RHO-LD-124, 1980, Laboratory Studies of Complexed Waste Slurry Volume Growth in Tank 241-SY-101, December.

Duckett, A. J., 1993, Tank Farms PRC Meeting Minutes for December 1, 1993 - Potential Reactive Component in Tank 241-T-111, (Letter to D. B. Bechtold et al., December 2, 1993).

Edwards, J. N., 1993, A Safety Assessment for Proposed Pump Mixing Operations to Mitigate Episodic Gas Releases in Tank 241-101-SY; Hanford Site, Richland, Washington, LA-UR-92-3196, Rev. 6. 
Homi, C. S., 1994, Tank Farm Off-normal RL-WHC-TANKFARM-1993-0110 Root Cause Analysis, Report, Westinghouse Hanford Company, Richland, Washington.

Kristofzski, J. G., 1994, Preliminary Review of Existing Data Packages Against Safety Screening Analyte Criteria, (Letter to C. Defigh-Price, February 3, 1994).

Lee, J. L., 1993, TWRS Plant Implementation Team, (letter to G. L. Borsheim et al., December 15, 1993), Westinghouse Hanford Company, Richland, Washington.

Nau, T., 1994, Root Cause Analysis for Occurrence Report RL-WHC-TANKFARM-1993-0105 on Methane Gas Discrepancy, Report, Westinghouse Hanford Company, Richland, Washington.

PNL-7598, Minutes of the Tank Waste Science Panel, meeting dated July 20, 1990.

PNL-7599, Minutes of the Tank Waste Science Panel, meeting dated September 13 through 14, 1990.

PNL-8048, Minutes of the Tank Waste Science Panel, meeting dated July 9 through $11,1991$.

PNL-8047, Minutes of the Tank Waste Science Panel, meeting dated November 11 through $13,1991$.

PNL-8845, Minutes of the Tank Waste Science Panel, meeting dated January 12 through 13, 1993.

Reynolds, D. A., C. E. Flanson, M. R. Kreiter, and J. W. Lentsch, 1992, Internal memo, Current Understanding of the Composition of Gas from 101-SY, May 4.

Ross, W. E., 1994, 242-A. Evaluation Due to T-111 Issue, (Letter to D. B. Engelman, February 15, 1994).

RL/WHC 1993a, Discovery of New Gas (Methane Gas) in Waste Tank 241-SY-101 Found When Reviewing Data from Event I at Levels of 1,000 PPM, Occurrence Report RL-WHC-TANKFARM-1993-0105.

RL/WHC 1993b, Potential Reactive Component in Tank 241-T-111, Occurrence Report RL-WHC-TANKFARM-1993-0110, December 10, 1993.

Turner, D. A., 1994, Reactive Component in Tank 241-T-111 (Letter to H. Babad et al., January 17, 1994), Westinghouse Hanford Company, Richland, Washington.

WHC, 1992a, Waste Tanks Administration Manual, WHC-IP-0842, Westinghouse Hanford Company, Richland, Washington, September 29. 
WHC, 1992b, T-111 Single-Shell Tank Characterization Data Package, WHC-SD-WM-DP-024, Westinghouse Hanford Company, Richland, Washington, October.

WHC, 1993a, Corrective Action Management, WHC-CM-1-4, Westinghouse Hanford Comipany, Richland, Washington, December 30.

WHC, 1993b, Evaluation of June 1993 Tank 241-SY-101 Gas Release Event, WHC-SD-EM-PE-050, Westinghouse Hanford Company, Richland, Washington, October. 


\section{DISTRIBUTION}

Number of Copies

3

26
U.S. Department of Energy-

Richland Operations Office

Hon, A.

A5-52

Westinghouse Hanford Company

$\begin{array}{ll}\text { Alumkal, W. } & \text { R2-52 } \\ \text { Borsheim, G. } & \text { R2-11 } \\ \text { Defigh-Price, C. } & \text { R3-08 } \\ \text { Dunford, G. } & \text { R1-51 } \\ \text { Engelman, D. (10) } & \text { R1-49 } \\ \text { Islam, M. } & \text { R3-08 } \\ \text { Lentsch, J. } & \text { R2-78 } \\ \text { Midgett, J. } & \text { N2-51 } \\ \text { Miskho, G. } & \text { R2-12 } \\ \text { Payne, M. } & \text { R2-50 } \\ \text { Raymond, R. } & \text { R2-54 } \\ \text { Thomas, D. } & \text { R3-08 } \\ \text { Trego, 1 } & \text { B3-02 } \\ \text { Turner, D. } & \text { R2-78 } \\ \text { Welty, R. } & \text { R1-80 } \\ \text { Winters, W. } & \text { T6-50 } \\ \text { Wodrich, D. } & \text { R2-79 }\end{array}$




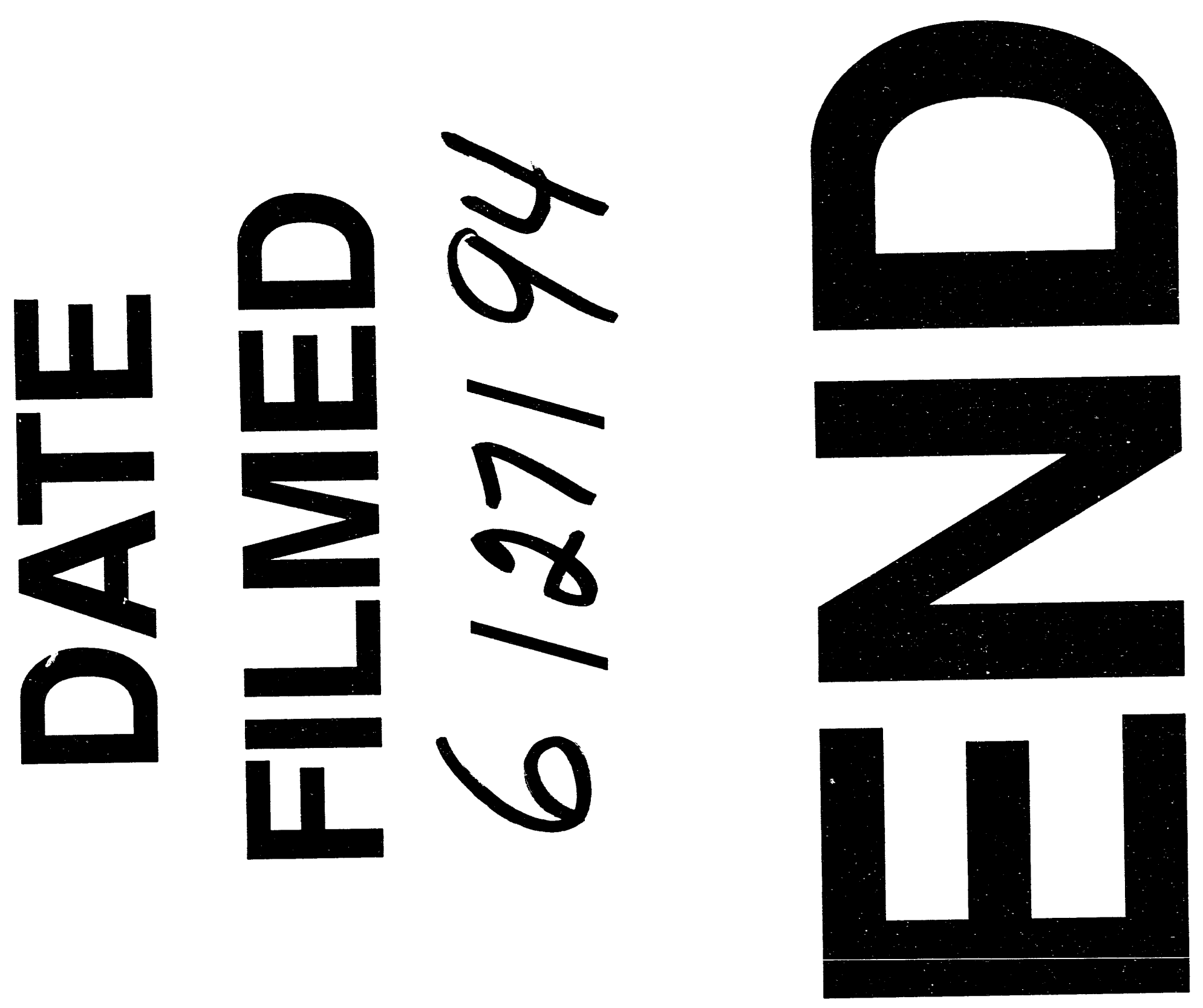


